\title{
POLA PERTUMBUHAN AYAM KAMPUNG LOKAL PERIODE STARTER PADA PEMELIHARAAN INTENSIF
}

\section{GROWTH PATTERN OF STARTER PERIODS OF THE DOMECTIC FOWL IN INTENSIVE FARMING SYSTEM}

\author{
Rajab \\ Jurusan Peternakan Fakultas Pertanian, Universitas Pattimura \\ 1) Jln. Ir. M. Putuhena, Kampus Poka - Ambon, Kode Pos. 97233 \\ Penulis korespondensi e-mail: rajab.amir@gmail.com

\begin{tabular}{|l|l} 
Diterima : 20 Agustus 2017 & Disetujui : 5 Oktober 2017
\end{tabular}

\section{Intisari} \\ Proses pertumbuhan merupakan hal sangat penting dalam tujuan produksi dari ternak pedaging karena \\ sangat berpengaruh secara ekonomis. Penelitian ini bertujuan untuk mengetahui dan menganalisis \\ pola pertumbuhan ayam kampung lokal periode starter yang dipelihara secara intensif. Sebanyak 101 \\ ekor ayam Kampung dipelihara, dan diukur bobot badan dan pertambahan bobot badannya selama 8 \\ minggu. Hasil penelitian menunjukkan bobot badan ayam sebesar $879 \mathrm{~g}$ dengan rata-rata bobot badan \\ 732,21 g pada umur 8 minggu, sedangkan pertambahan bobot badannya dapat mencapai 10,61 g / \\ hari. Guna menunjang pertumbuhan ayam Kampung yang optimal, penggunaan bibit yang segalur \\ serta tata kelola kandang dan peralatannya sangat diperlukan guna mengurangi stress pada ternak dan \\ mencegah kanibalisme pada ayam.
}

Kata Kunci : pola pertumbuhan, ayam kampung, sistem pemeliharaan intensif

\section{Abstract}

Growth, which is defined as an increase in body size per unit time, is one of the most important characteristics of farm animals. The purpose of this research was to know and analysis the growth pattern of native fowl ranging in intensive farming system. Animals used in this study consists 101 native fowls which measured in 8 weeks of age to defined bodi weight and growth pattern. Results of analisys showed that the body weight of chicken was 732,21 g on age of 8 weeks with $10,61 \mathrm{~g} /$ day of growth rate. As a result, growth pattern fitted to the body weight - age data from native fowls might suggest us to used intensif farming system in native fowls rearing..

Keywords: growth pattern, native fowl, intensive farming system

\section{PENDAHULUAN}

Ayam Kampung merupakan plasma nutfah ternak asli Indonesia, sebagai salah satu aset nasional yang turut menunjang kehidupan sosial dan ekonomi masyarakat, banyak dimiliki dan dipelihara oleh masyarakat khususnya di pedesaan, dengan tujuan sebagai sumber gizi keluarga, sebagai tabungan dan sumber pendapatan keluarga. Ayam Kampung merupakan ternak komoditi lokal di Indonesia yang kehidupannya sudah melekat dengan masyarakat atau sudah menyatu dengan pola hidup agraris orang Indonesia (Sulandri dkk., 2007). Sejak dahulu ayam Kampung sudah dikenal sebagai ternak penghasil daging dan telur. Namun perkembangannya kalah cepat dengan ayam ras pedaging maupun petelur. Perkembangan usaha ayam Kampung umumnya masih bersifat tradisional dan semi intensif. Pemeliharaannya masih merupakan usaha sambilan tanpa 
memperhitungkan untung rugi, sedangkan pemeliharaan secara intensif belum menunjukkan perkembangan seperti halnya ayam ras (Nurkasanah, 2002).

Perhatian khusus perlu diberikan pada pengembangan peternakan rakyat secara berkesinambungan. Ayam Lokal seperti halnya ayam Kampung merupakan plasma nutfah Indonesia yang sangat potensial untuk dikembangkan, karena secara geografis sangat mendukung dengan penyebaran populasi hampir di seluruh pedesaan di Indonesia. Peluang usaha ternak ayam Kampung sangat luas ditinjau dari agroekosistem dan lingkungan hidup, seiring dengan meningkatnya pendapatan dan kesadaran masyarakat terhadap pentingnya kuantitas dan kualitas bahan pangan yang bergizi dan aman dikonsumsi (Elizabeth dan Rusdiana, 2012). Keuntungan yang dapat diperoleh dari pemeliharaan ayam Kampung antara lain : dapat diusahakan pada lahan yang tidak begitu luas, tidak memerlukan teknologi tinggi (cukup dengan pemeliharaan intensif), daya tahan tubuh lebih kuat dibanding ayam ras, daging lebih padat dan lebih enak, harga jual lebih tinggi dibanding ayam ras, hemat tenaga kerja, kotoran dan bulunya dapat dimanfaatkan, membuka lapangan kerja baru baik unutk keluarga maupun orang lain, dan dapat meningkatkan pendapatan dari sektor peternakan (Sartika dan Iskandar, 2007).
Pengembangan sumber plasma nutfah ternak lokal seperti halnya ayam kampung tidak akan mudah dilakukan sebelum diperoleh model perkembangan populasi dan model pola pertumbuhan ternak itu sendiri yang akurat dan valid. Proses pertumbuhan merupakan hal sangat penting dalam tujuan produksi dari ternak pedaging karena dalam proses pertumbuhan termasuk diantaranya proses deposisi lemak dalam otot yang menjadi penting yang sangat berpengaruh secara ekonomis (Keskin et al., 2009; Khan et al., 2007).

Pola Pertumbuhan merupakan pencerminan kemampuan suatu individu atau populasi untuk mengaktualisasikan diri sekaligus sebagai ukuran akan berkembangnya bagianbagian tubuh sampai mencapai ukuran maksimal (dewasa) pada kondisi lingkungan yang ada. Lingkungan tersebut bisa berupa level produksi individu, kuantitas dan kualitas pakan, lokasi dan lingkungan secara umum (Thariq et al., 2011). Salah satu alasan mengetahui pola pertumbuhan adalah adanya interpretasi biologis dari parameter pertumbuhan akibat pengaruh genetik dan lingkungan untuk tiap spesies ternak dan lingkungannya. Beberapa parameter yang sering menjadi kajian menarik yaitu bobot dewasa, rataan pertumbuhan dan ratan kecepatan menuju dewasa (Karakus et al., 2008). Penelitian ini bertujuan untuk mengetahui dan menganalisis pola 
pertumbuhan ayam kampung lokal periode

\section{METODE PENELITIAN}

\section{Lokasi dan Waktu Penelitian}

Penelitian ini dilaksanakan selama empat (4) bulan, mulai bulan Desember

\section{Metode Pengumpulan Data}

Materi yang digunakan selama penelitian ini terdiri dari : (1) Peralatan, antara lain dua buah mesin tetas berkapasitas 100 butir dan perlengkapannya, kandang pemanas (brooder) berupa kandang koloni, lampu pijar 15 watt, tempat makan, tempat minum, sprayer, spoid, sapu, timbangan digital dengan satuan terkecil $0,1 \mathrm{~cm}$, thermometer, dan alat tulis menulis ; sedangkan (2) Bahan, meliputi : telur tetas 200 butir, ransum jadi 'Br-1' produksi PT. Japfa Comfeed, dedak, limbah perikanan, air minum, serbuk gergaji untuk litter, vaksin, vitachick, vitastress, obat-obatan dan desinfektan.

Penelitian ini dilaksanakan dalam tiga (3) tahapan : (1) Tahap Persiapan yang dilakukan sebelum anak ayam dipelihara dalam kandang, yaitu meliputi : proses penetasan, pembuatan kandang dan pengadaan peralatannya, formulasi pakan dan penyediaan obat-obatan, serta persiapan saat anak ayam masuk kandang. (2) Tahap Pemeliharaan yang meliputi : (a) Pemeliharaan periode starter (umur $1-4$ minggu), dimana anak ayam (DOC) pertama starter yang dipelihara secara intensif.

2014 sampai Maret 2015 pada peternakan ayam Kampung milik Bapak Umar di Dusun Taeno Atas Negeri Rumah Tiga Kota Ambon.

kali masuk diberi minum air gula yang dicampur dengan vitachick. Setelah satu jam, baru DOC diberi makan sedikit demi sedikit dengan pakan pabrik $70 \%$ ditambah dedak 30\%. Makanan diberikan dua kali sehari secara ad libitum. Air minum dicampur dengan vitachicks sebanyak 2 sendok makan tiap 2,5 liter air dan minum diberi secara ad libitum. Pada umur 4 hari, dilakukan vaksinasi melalui tetes mata. (b) Pemeliharaan periode starter (umur 5-8 minggu), dimana satu (1) hari sebelumnya ayam dipuasakan setengah hari untuk dilakukan vaksinasi. Vaksinasi kedua umur 4 minggu dilakukan melalui air minum. Guna mencegah stress air minum tetap dicampur dengan vitastress (1 sendok tiap 3,5 liter air). Pemeliharaan periode ini telah melalui periode kritis, tetapi vitachick dan vitastress tetap diberikan jika terdapat gangguan dan anak ayam stress. Air minum diberikan secara ad libitum. Pemberian makan berupa campuran pakan pabrik 30\%, dicampur $70 \%$ bahan lain berupa dedak, ela sagu, limbah ikan, daun kangkung yang diberikan secara ad libitum. (3) Tahap Pengumpulan Data, yang dilakukan satu minggu sekali selama 8 minggu. Pencatatan 
data dilakukan terhadap semua individu ayam yang telah diberi nomor sebagai identitasnya.

Peubah yang diamati dalam penelitian ini meliputi : bobot badan dan pertambahan bobot badan. Bobot badan, merupakan bobot hidup ayam, diukur tiap minggu menggunakan timbangan digital dalam satuan gram. Pertambahan bobot badan, dihitung berdasarkan kenaikan bobot badan setiap minggunya dalam satuan gram / hari.

Data hasil penelitian ini dianalisa secara deskriptif dan kuantitatif. Secara deskriptif data dianalisa sesuai tujuan penelitian. Secara kuantitatif, rata-rata, simpangan baku dan koefisien keragaman setiap peubah dihitung.Untuk mengetahui

\section{HASIL DAN PEMBAHASAN}

Pola Pertumbuhan Ayam Periode Starter I (Umur 0 - 4 minggu)

Periode pemeliharaan ayam sampai umur 4 minggu merupakan proses kritis karena masa pembentukan dan pertumbuhan bulu sehingga pemeliharaan dilakukan pada kandang pemanas (brooder). Rataan, simpangan baku, dan koefisien keragaman bobot badan dan pertambahan bobot badan ayam Kampung umur 1 hari sampai 4 minggu seperti tertera pada tabel 1. Hasil penelitian menunjukkan rataan bobot badan ayam Kampung sebesar 30,81 g untuk ayam berumur 1 hari ; dan 46,83 g, 134,81 g, $250,73 \mathrm{~g}$ serta $337,44 \mathrm{~g}$ dengan pertambahan keragaman bobot badan ayam, digunakan rumus koefisien keragaman sebagai berikut (Kaps dan Lamberson, 2004) :

$$
\begin{gathered}
K K=\frac{s}{\bar{y}} \times 100 \%, \quad \text { dimana }: \mathrm{KK}= \\
\text { koefisien keragaman, }
\end{gathered}
$$

$\mathrm{S} \quad=$ simpangan baku

$\bar{y} \quad=$ rataan berat badan

Pola pertumbuhan ayam Kampung yang menjelaskan hubungan antara umur pemeliharaan dan bobot badan digambarkan dalam bentuk kurva grafik garis ( line chart ). Analisis data dan pembuatan line chart menggunakan software MINITAB versi 14.0.

bobot badan setiap minggunya sebesar 16,01 g/minggu, 87,$99 ; 115,92$ dan 86,72 g/minggu masing-masing untuk ayam berumur 1, 2, 3, dan 4 minggu. Jika dihitung setiap harinya maka rata-rata pertambahan bobot badan ayam Kampung umur 1 hari sampai 4 minggu sebesar 10,96 g/hari.

Koefisien keragaman ayam Kampung lebih besar dari $10 \%$ (berkisar antara $10,39-27,98 \%$ ) yang menunjukkan masih besar variasi bobot badan dan pertumbuhan ayam Kampung. Besarnya keragaman tersebut diakibatkan oleh perbedaan galur ayam Kampung yang dipelihara, dan jumlah konsumsi pakan. 
Ayam Kampung yang digunakan dalam penelitian ini kemungkinan merupakan galur ayam Bangkok, ayam Arab, Ayam Lokal, Ayam Kancingan serta berbagai galur tersebut. Perbedaan galur juga berdampak terhadap adanya kompetisi di dalam kamdang untuk mengkonsumsi pakan.

kemungkinan perkawinan silang antar

Tabel 1. Statistik bobot badan dan pertambahan bobot badan ayam Kampung umur 0 sampai 4 minggu yang dipelihara secara intensif.

\begin{tabular}{lcccccc}
\hline \multirow{2}{*}{ Statistik } & \multicolumn{4}{c}{ Bobot Badan Ayam Kampung Periode Starter I } & \multirow{2}{*}{ PBB } \\
\cline { 2 - 5 } & DOC & $\begin{array}{c}\mathbf{1} \\
\text { minggu }\end{array}$ & $\begin{array}{c}\mathbf{2} \\
\text { minggu }\end{array}$ & $\begin{array}{c}\mathbf{3} \\
\text { minggu }\end{array}$ & $\mathbf{4}$ minggu & \\
\hline $\mathrm{N}$ & 106 & 106 & 106 & 105 & 105 & 105 \\
Minimum & 25 & 33 & 73 & 153 & 201 & 5,93 \\
Maximum & 41 & 54 & 210 & 309 & 450 & 14,86 \\
Rata-Rata & 30,81 & 46,83 & 134,81 & 250,73 & 337,44 & 10,96 \\
Simpangan Baku & 3,77 & 4,87 & 37,72 & 45,40 & 56,14 & 2,01 \\
Coef. Ragam & 12,24 & 10,39 & 27,98 & 17,24 & 16,64 & 18,28 \\
\hline
\end{tabular}

Pertumbuhan ayam Kampung yang umumnya diukur dengan menimbang bobot badannya selama periode tertentu sangat bervariasi, karena ayam Kampung memiliki keragaman fenotip maupun genotip pada setiap individu cukup tinggi (Mansjoer, 1989; Sulandri et al.,2006). Dengan memanfaatkan keragaman tersebut, usaha untuk memperbaiki produktivitas ayam Kampung melalui penerapan sistem pemeliharaan secara semi intensif atau bahkan intensif diharapkan mempunyai respons yang positif (Sartika dan Gunawan, 2007).

Pola pertumbuhan ayam Kampung umur 1 hari sampai 4 minggu dalam penelitian ini digambarkan dalam bentuk grafik seperti pada gambar 1. Hasil penelitian menunjukkan terjadi pertumbuhan yang lambat dari umur 1 hari sampai 1 minggu, kemudian pertumbuhannya cepat sampai umur 3 minggu, dan memasuki umur 4 minggu grafik pertumbuhannya agak menurun. Lambatnya pertumbuhan ayam pada minggu pertama disebabkan oleh adanya proses aklimatisasi ternak akibat pemindahan dari mesin tetas ke kandang pemanas. Hal lainnya adalah anak ayam sampai umur 4 hari umumnya rendah konsumsi pakannya karena masih memanfaatkan pakan cadangan dalam tubuhnya. Sedangkan menurunnya pertumbuhan pada umur 4 minggu disebabkan oleh stress pada ternak akibat proses puasa ayam yang sengaja dilakukan menjelang vaksinasi pada umur tersebut. 


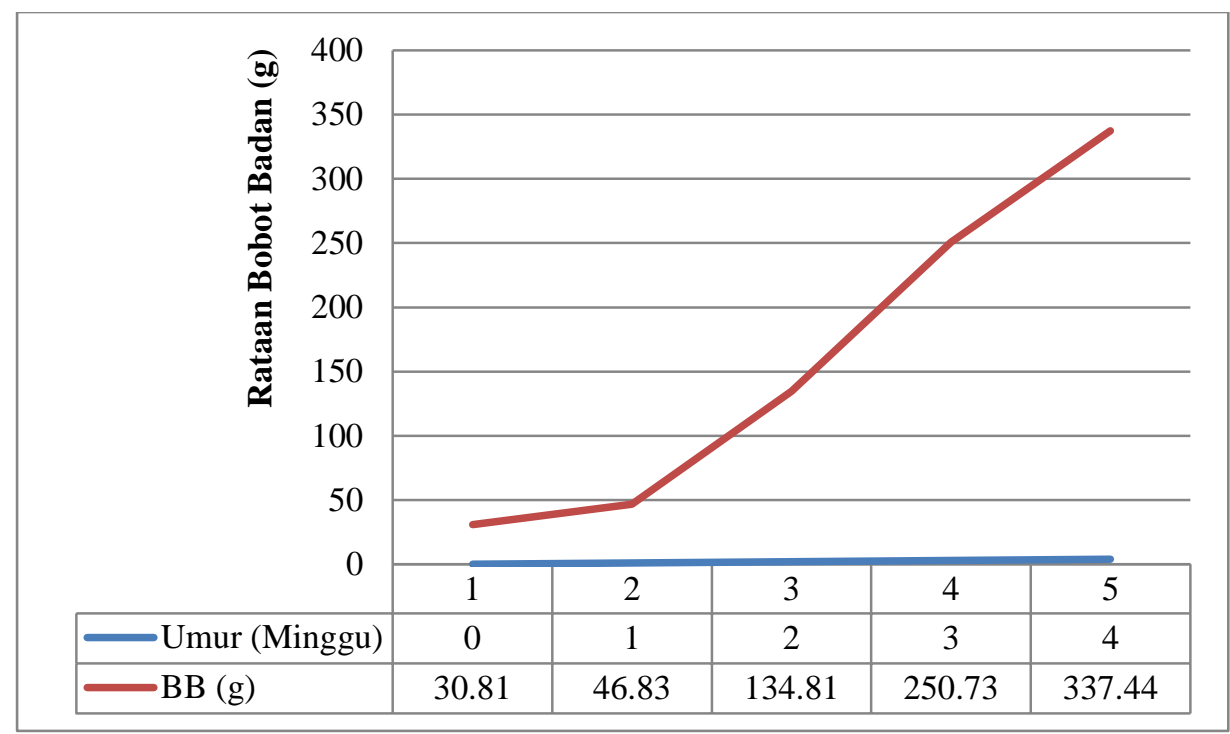

Gambar 1. Grafik Pola Pertumbuhan Ayam Kampung Umur 0 sampai 4 Minggu yang Dipelihara secara Intensif

\section{Pola Pertumbuhan Ayam Periode Starter \\ II (Umur 5 - 8 minggu)}

Rataan, simpangan baku, dan koefisien keragaman bobot badan dan pertambahan bobot badan ayam Kampung umur 5 sampai 8 minggu seperti tertera pada tabel 2. Pemeliharaan ayam pada periode ini telah melewati masa kritis. Hasil penelitian menunjukkan rataan bobot badan ayam Kampung umur 5, 6, 7 dan 8 minggu masing-masing sebesar 435,08 g, 579,90 g, 633,25 g, dan 732,21 g. Koefisien keragaman ayam Kampung pada periode ini pun masih lebih besar dari $10 \%$ (berkisar antara $12,44-16,64 \%$ ) yang menunjukkan performa bobot badan ayam Kampung masih sangat beragam. Seperti dijelaskan sebelumnya besarnya variasi bobot badan tersebut diakibatkan oleh faktor bibit dan pakan. Faktor lain yang berpengaruh terhadap besarnya keragaman bobot badan ayam Kampung dalam penelitian ini adalah aspek jenis kelamin, dimana ayam jantan dan betina dipelihara bersama dalam satu kandang.

Tabel 2. Statistik bobot badan dan pertambahan bobot badan ayam Kampung umur 5 sampai 8 minggu yang dipelihara secara intensif.

\begin{tabular}{lccccc}
\hline \multirow{2}{*}{ Statistik } & \multicolumn{3}{c}{ Bobot Badan Ayam Kampung Periode Starter II } & \multirow{2}{*}{$\begin{array}{c}\text { PBB } \\
\text { (gr/hr) }\end{array}$} \\
\cline { 2 - 4 } & $\mathbf{5}$ minggu & $\mathbf{6}$ minggu & $\mathbf{7 ~ m i n g g u}$ & $\mathbf{8 ~ m i n g g u}$ & \\
\hline $\mathrm{N}$ & 105 & 101 & 101 & 101 & 101 \\
Minimum & 260 & 353 & 364 & 602 & 5,65 \\
Maximum & 566 & 761 & 788 & 879 & 20,04 \\
Rata-Rata & 435,08 & 579,90 & 633,25 & 732,21 & 10,61 \\
Simpangan Baku & 72,39 & 91,79 & 84,32 & 91,08 & 4,75 \\
Coef. Ragam & 16,64 & 15,83 & 13,32 & 12,44 & 44,74 \\
\hline
\end{tabular}


Hasil penelitian menunjukkan pertambahan bobot badan setiap minggunya sebesar 97,64 g/minggu, 144,81;53,36 dan 98,95 g/minggu masing-masing untuk ayam berumur 5, 6, 7, dan 8 minggu, dengan ratarata pertambahan bobot badan ayam Kampung umur 5 hari sampai 8 minggu sebesar 10,61 g/hari. Pertambahan bobot badan ayam Kampung periode ini digambarkan dalam bentuk grafik pola pertumbuhan seperti tertera pada gambar 2 . Berdasarkan grafik tersebut sampai umur 6 minggu pertumbuhan ayam bergerak naik dengan cepat, tetapi memasuki umur 7 minggu pertumbuhannya agak menurun. Hal ini diduga akibat ayam mengalami stress setelah pergantian kandang, dimana ayam dipindakan ke kandang yang lebih besar kapasitasnya. Pergantian kapasitas kandang dilakukan setelah 4 ekor ayam mati akibat kanibalisme.

Dalam proses pemeliharaan ayam secara intensif, tata kelola kandang menurut kapasitas tampung ternak dan pengaturan jumlah tempat makan dan minum yang sesuai sangat diperlukan untuk mencegah kanibalisme dan kompetisi antar ternak dalam mengkonsumsi pakan. Sebagai hasilnya seperti ditunjukkan dalam penelitian ini dimana mortalitas atau jumlah ayam yang mati selama periode 8 minggu pemeliharaan hanya sebesar $4,72 \%$ atau 5 ekor yang mati dari total 106 ekor ayam yang dipelihara.

Sebagai catatan dalam penelitian ini, ayam umur 8 minggu telah dihargai oleh konsumen pemilik rumah makan seharga $\mathrm{Rp}$ 40.000 sampai $\mathrm{Rp} 60.000$ per ekornya. Pemanfaatan sumber daya lokal seperti limbah sagu dan limbah perikanan sebagai pakan ayam Kampung dalam penelitian ini menunjukkan hasil yang baik sebagai alternative pengganti pakan pabrik yang mahal ataupun ketergantungan terhadap dedak padi. Hanya saja diperlukan penelitian lanjutan untuk mengetahui formulasi yang lebih tepat dari pemanfaatan sumber daya lokal seperti limbah sagu dan perikanan sebagai sumber pakan untuk mempercepat pola pertumbuhan ayam Kampung. 


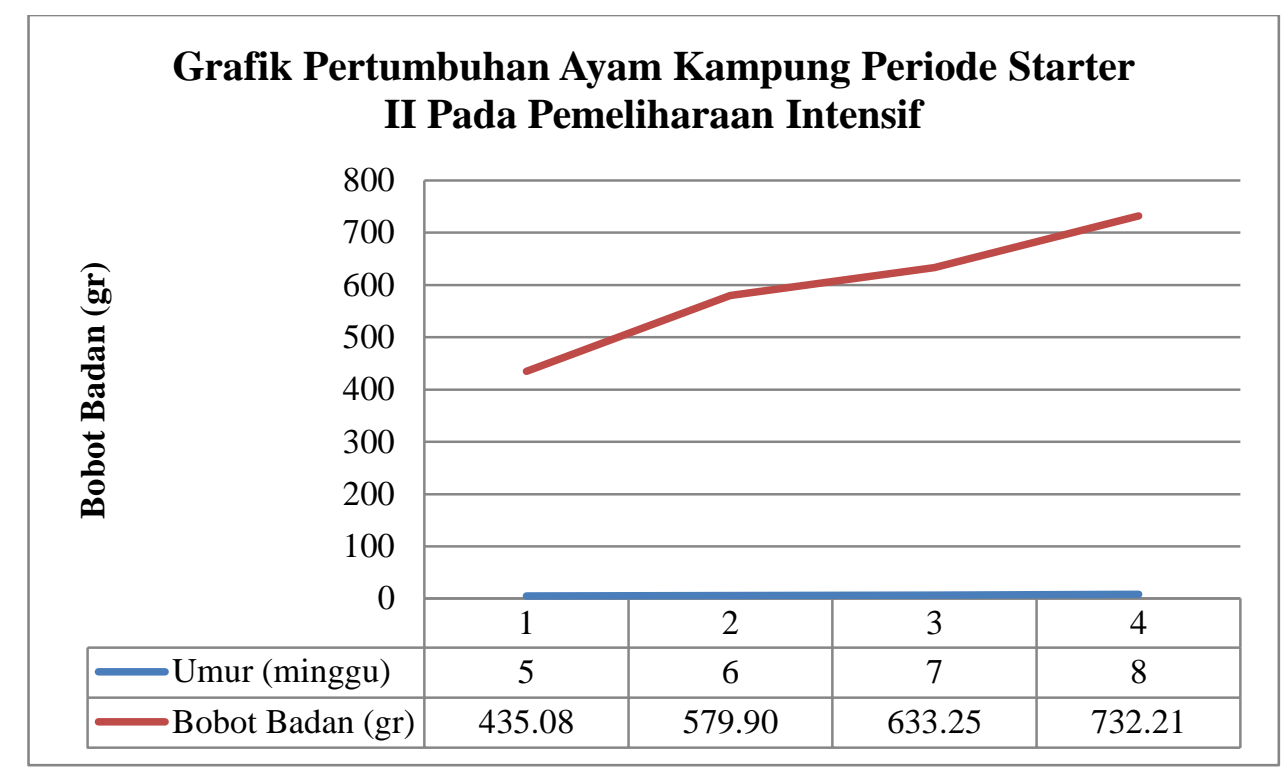

Gambar 2. Grafik Pola Pertumbuhan Ayam Kampung Umur 5 sampai 8 Minggu yang Dipelihara secara Intensif

\section{KESIMPULAN}

Ayam kampung yang dipelihara secara intensif dapat mencapai bobot badan $879 \mathrm{~g}$ dengan rata-rata bobot badan $732,21 \mathrm{~g}$ pada umur 8 minggu, sedangkan pertambahan bobot badannya dapat mencapai 10,61 g / hari. Sistem pemeliharaan ayam secara intensif juga berkontribusi terhadap rendahnya angka mortalitas ayam Kampung yang hanya $4,72 \%$.

\section{DAFTAR PUSTAKA}

Elizabeth, R. dan S. Rusdiana. 2012. Perbaikan Manajemen Usaha Ayam Kampung Sebagai Salah Satu Sumber Pendapatan Keluarga Petani Di Pedesaan. Workshop Nasional Unggas Lokal Tahun 2012. Hal: 93-101.

Kaps, M and W. Lamberson. 2004. Biostatistics for Animal Science. CABI Publishing. Cambridge.

Karakus, K., E. Eyduran., D. Kum., T.
Guna menunjang pertumbuhan ayam Kampung yang optimal, penggunaan bibit yang segalur serta tata kelola kandang dan peralatannya sangat diperlukan guna mengurangi stress pada ternak dan mencegah kanibalisme pada ayam.

Ozdemir and F. Cengiz. 2008. Determination of the best growth curve and measurement interval in Norduz male Lambs. J. Anim. Vet. Advances, 7[11]: 1464-1466.

Keskin. I., B. Dag, V. Sariyel., and M. Gokmen. 2009. Estimation of growth curve parameters in Konya Merino sheep. South African J.Anim.Sci., 39 [2]:163-169. 
Khan. S. A., M. A. Khan., and S. Mehmood. 2007. Genetic resources and diversity in Pakistani sheep. Intl. J. Agri. Bio. 9 [6]: 941-944.

Mansjoer, S.S. 1989. Pengembangan ayam Kampung di Indonesia. Prosiding Seminar Peran Unggas Kampung di Indonesia, Lustrum V. Semarang: Fakultas Peternakan, Universitas Diponegoro.

Nurkasanah, B. 2002. Analisis Faktor-Faktor yang Mempengaruhi Perkembangan Usaha Ternak Ayam Kampung (Studi Kasus di Desa Karacak, Kecamatan Leuwiliang, Kabupaten Bogor). [Skripsi]. Bogor: Jurusan Ilmu Produksi Ternak, Institut Pertanian Bogor.

Sartika, T. dan B. Gunawan. 2007. Karakteristik Sifat-Sifat Produktivitas Ayam Kampung Betina Fase Produksi Pada Populasi Dasar Seleksi. Prodising Seminar Nasional Teknologi Peternakan dan Veteriner Tahun 2007. Hal: 576582.

Sartika, T, dan S. Iskandar. 2007. Mengenal Plasma Nutfah Ayam Indonesia dan Pemanfaatannya. Balai Penelitian Ternak Puslitbangnak. Bogor.
Sulandri, S., M.S.A, Zein, T. Sartika and S. Paryanti. 2006. Molecular Characterization of Indonesian local chicken based on HVI, Dloop mitochondria analysis. Research report of the project competitive research, Indonesian Research Centre (LIPI), Indonesia.

Sulandri, S., M.S.A. Zein, Sri Paryanti, T. Sartika, J.H.P. Sidadolog, M. Astuti, T. Widjastuti, E. Sujana, I. Setiawan, D. Garnida, S. Iskandar, D. Zainuddin, T. Herawati, I. Wayan dan T. Wibawan. 2007. Keanekaragaman Sumber Daya Hayati Ayam Lokal Indonesia. Manfaat dan Potensi. Jakarta: Pusat Penelitian Biologi LIPI.

Thariq, MM., M. A. Bajwa, A. Waheed, E. Eyduran, F. Abbas, F. A. Bokhari and A. Akbar. 2011. Growth Curve in Mengali Sheep Breed. J.of Aniaml and Plant Sci,21 [1]: 5-7. 